\title{
The British Equality Act 2010 and the Foundations of Legal Knowledge
}

\author{
James Hand*, Bernard Davis and Charles Barker \\ (Associate Senior Lecturer, Senior Lecturer and Principal Lecturer) \\ School of Law, \\ Portsmouth Business School, \\ University of Portsmouth, \\ Richmond Building, \\ Portland Street, \\ Portsmouth \\ PO1 3DE \\ * Corresponding author email: James.Hand@port.ac.uk, Tel: 02392844818 \\ (other authors' email: Bernard.Davis@ port.ac.uk, Tel: 02392844087 \\ Charles.Barker@port.ac.uk, Tel: 02392 844726)
}

\begin{abstract}
The Equality Act 2010, in its content and passage through Parliament, provides a rare example of an Act that engages, to some extent, with all seven foundations of legal knowledge (the English compulsory subjects upon which other legal subjects build). This article examines the Equality Act 2010 through the prism of the foundations and, in light of ongoing reform, contends that while anti-discrimination law is an important subject it should not join the list of foundations but rather that awareness and appreciation of those foundations can provide a richer understanding of such laws as the Equality Act 2010.
\end{abstract}

Keywords: Equality, Discrimination, Legal Education and Training Review 


\title{
The British Equality Act 2010 and the Foundations of Legal Knowledge
}

\author{
Introduction
}

The Equality Act 2010 was designed to unify, simplify and strengthen the myriad pieces of British anti-discrimination law which had emerged over the previous 40 years as more and more grounds (or protected characteristics) were introduced and amendments to legislation (often European-derived) were made. ${ }^{1}$ Alongside this illustrious, and partially fulfilled, aim, the Equality Act 2010 also has a number of other distinguishments. It was one of the last Acts of the Labour Government of 1997 - 2010, receiving Royal Assent during Prorogation, and the first to trial interleaving the explanatory notes with the Bill so as to aid user engagement, making it more accessible to both the specialist and the general reader. ${ }^{2}$ It was one of very few Bills to have been introduced in one parliamentary session and to have been carried over to another (its Commons Committee stage having taken place in the 2008/2009 session with Report and Third Reading taking place in the 2009/2010 session) ${ }^{3}$ and yet,

\footnotetext{
${ }^{1}$ As Race, then Disability, Religion or Belief, Sexual Orientation and Age joined Sex (including pregnancy/maternity, marriage/civil partnership and gender reassignment), the British antidiscrimination statute book grew to "nine major pieces of discrimination legislation, around 100 statutory instruments setting out connected rules and regulations and more than 2,500 pages of guidance and statutory codes of practice' (Government Equalities Office, Framework for a fairer future - the Equality Bill (Cm 7431, 2008), 6). This article refers to British discrimination law, rather than UK law, as discrimination legislation is a devolved, or transferred, power under the Northern Ireland Act 1998 and even before was subject to a separate system. Very few provisions of the Equality Act 2010 relate to Northern Ireland.

${ }^{2}$ Following a report of the Procedure Committee recommending an experiment, the Bill and Explanatory Notes were made available as i) a PDF with both texts side-by-side, ii) HTML with the texts side-by-side, and iii) an interwoven web page (HTML). This was deemed a success by Harriet Harman but who nonetheless considered that the costs and the benefit of doing so should be assessed on a bill by bill basis (Harman, Letter to House of Commons Procedure Committee (January 2010) <www.publications.parliament.uk/pa/cm200910/cmselect/cmproced/memo/interleaving/ucm0102.htm> accessed 25 January 2013). See also UK Parliament Labs, 'Equality Bill published in trial format' (27 April 2009) <http://parliamentlabs.wordpress.com/2009/04/27/equality-bill-trial-format/\#comments> accessed 25 January 2013.

${ }^{3}$ It was the seventh bill to be carried over since the introduction in 2004 of permanent procedures allowing bills to be carried over (House of Commons, Standing Orders of the House of Commons Public Business, November 2007, HC 105 2007-08, SO No. 80A) and only the 14th bill to have been
} 
despite this, the Bill, as Lord Lester noted, 'reached [the House of Lords] very late, with parliamentary time scarce before the general election' ${ }^{4}$ with scrutiny in the Commons having been far from full. ${ }^{5}$ It is also a rare example of an Act which affects, is affected by, or is an example of, all seven foundations of English law. 2015 will see a five-year review of the Equality Act $2010^{6}$ as well the continuing consideration by the professional bodies of the Legal Training and Education Review which could revolutionise legal training in England and Wales. ${ }^{7}$

The seven foundations of legal knowledge were laid down by the English professional bodies in 1995 but they were predominantly built from the previous six compulsory subjects (the five core subjects identified by the 1971 Ormrod report $^{8}-$ constitutional, criminal, land, contract and tort - together with the later addition of equity), but becoming less prescriptive as to the curriculum within them while adding European Law as the seventh. ${ }^{9}$ The underpinning rational for the seven foundations can be seen in the 1995 Joint Announcement by the Law Society of England and Wales and the General Council of the Bar which stated the foundation subjects arise from the fact that all prospective solicitors and barristers need a common grounding in these seven law foundations and because the vocational courses build on the students' knowledge of these foundations and must therefore be able to presuppose certain levels of familiarity, knowledge, awareness and

carried over a parliamentary session since the first ad-hoc carry over of a bill (the Financial Services and Markets Bill 1998-99).

${ }^{4}$ HL Deb 23 March 2010, vol 718, col 863.

${ }^{5}$ Eg HC Deb 2 December 2009, vol 501, col 1193 (Dr Evan Harris); col 1183 (Mr Harper), col 1225 (Miss Widdecombe), col 1230 (Mark Pritchard).

${ }^{6}$ HC Deb 1 May 2014, vol 579, col 778WS (Mrs Grant).

${ }^{7}$ It is possible that the Solicitors Regulation Authority in shifting to an outcomes focused process may cease to prescribe content (they have already cut back on quality assurance -

http://www.sra.org.uk/sra/news/press/streamline-training-regs.page)) and the Bar Standards Board have embarked on a three-year 'Future Bar Training' programme of reform (although a degree will remain a requirement: https://www.barstandardsboard.org.uk/qualifying-as-a-barrister/future-bar-training/).

${ }^{8}$ The Report of the Committee on Legal Education, Cmnd 4595. The seven foundations relate to England and Wales as Scotland has a separate system of legal education (and representation).

${ }^{9}$ A Boon and J Webb, 'Report to the Law Society of England and Wales on The Consultation \& Interim Report on The Training Framework Review (2002), para 36. 
appreciation. The foundations... also provide the basis for continuing legal

education and professional development by providing solicitors and barristers

with the necessary knowledge to enable them to break into new areas of law. ${ }^{10}$

While the concept of there being seven foundations has been subject to strong criticism by some eminent academics, notably Peter Birks, ${ }^{11}$ the general concept of a general grounding has proved enduring within the qualifying law degree and the postgraduate conversion course (the Legal Executive route, by contrast, having early specialisation as a hallmark). ${ }^{12}$ Indeed, the current Legal Education and Training Review, while not wanting to pre-empt further work by the regulatory bodies regarding outcomes, noted that 'the range of evidence points to the existing Foundation subjects as a reasonable proxy for what is required ${ }^{13}$ but has recommended that there should be further limited prescription as to what is required within the subjects. ${ }^{14}$

For the foundations to have any worth, it is inevitable that the wide range of other topics - to quote Peter Birks the 'hundred others' that the professions 'could not care less about' (and including 'very important subjects' which he feared could be 'starved to extinction while all available energy is applied to the sustenance of the

\footnotetext{
${ }^{10}$ Advisory Committee on Legal Education and Conduct, First report on legal education and training (ACLEC 1996), 117 (Annex D).

${ }^{11}$ Who, eg, referred to 'to this miserable list of now seven compulsory subjects' and opined that 'professions' systematic indifference to the well-being of all but seven subjects is not only myopic but bewildering' (P Birks, 'Compulsory Subjects: Will the Seven Foundations ever Crumble?' [1995] 1 WebJCLI).

${ }^{12}$ Legal Executives are the third branch of the profession in England and Wales.

${ }^{13}$ LETR (2013) Setting Standards: The Future of Legal Services Education and Training Regulation in England and Wales (The Final Report of the Legal Education and Training Review independent research team), para 7.93. See also paras 2.52-2.58.

${ }^{14}$ LETR (2013) Setting Standards: The Future of Legal Services Education and Training Regulation in England and Wales (The Final Report of the Legal Education and Training Review independent research team), para 4.103. The number and content of the compulsory subjects vary across the Commonwealth although there appears to be a common core of five or six of the seven foundations (EU law being less relevant for most and India excluding Equity in an otherwise much more extensive list). Company and/or commercial law is included in, for example, Scotland, Canada, Australia and India (LETR (2013), para 4.98) but not England and Wales or Malaysia (see e.g. http://www.malaysianbar.org.my/admission requirements.html) at the academic stage (company law is, however, a component of the English and Welsh vocational stage for solicitors).
} 
subjects which are strong and abundant' $)^{15}$ - build on at least one of the foundations. Thus, labour law is founded on contract and tort (with some public law), company law on equity and contract, and the law of armed conflict on crime and public law, etc. While some subjects, family law for example, could conceivably touch on all of the English foundations, ${ }^{16}$ it is unusual for a single Act do so. The content of the Equality Act 2010, and the circumstances of its creation, cause it to engage - to varying extents - with all seven.

However, it is worth considering whether the seven foundations achieve their aim of providing "[legal practitioners] ... with the necessary knowledge to enable them to break into new areas of law ..." and the Equality Act 2010 is a topical and arguably capacious prism through which to do that. Discrimination (or equality) law may not be a mainstream academic subject and it does not, and arguably should not, form one of the distinct foundations but 'familiarity, knowledge, awareness and appreciation' of those foundations can provide a richer understanding of the scope, complexity and the context of what is nonetheless an important piece of legislation. If the seven foundations are a good basis for legal education, one might reasonably expect some of them to be reflected in any legal topic. It is suggested, as examined below, that the Equality Act is, in fact, a (rare) example of an Act which does reflect all seven foundations of English law.

The Equality Act 2010: General framework and the Law of Tort

As Sandra Fredman noted in 2001, '[t]here is no general equality guarantee; instead, a relatively sophisticated set of anti-discrimination statutes operates within a narrow

\footnotetext{
${ }^{15}$ P Birks, 'Compulsory Subjects: Will the Seven Foundations ever Crumble?' [1995] 1 WebJCLI.

${ }^{16}$ Eg public law child orders, criminal domestic violence, property rights, constructive trusts, prenuptial contracts, tortious harassment and European jurisdictional issues.
} 
area'. Back then there were only four main protected grounds or characteristics (the original two from the 1970s of sex and race, with the addition of disability in 1995 and gender reassignment in 1999). ${ }^{17}$ The years since have seen the area increase in size, with a number of new Acts passed and Regulations tabled, and then the subsequent unification of those nine main pieces of legislation ${ }^{18}$ into the single Equality Act; but the lack of a general equality guarantee remains. Then, and now, British anti-discrimination law primarily sets outs to prohibit certain activities with regard to certain characteristics in certain circumstances and it does so through creating a statutory tort. The Equality Act 2010 is principally a restatement of the tort. Since the seminal Sex Discrimination Act 1975 (SDA 1975), the successive pieces of legislation - providing protection for new protected characteristics ${ }^{19}$ or extending the coverage of existing characteristics ${ }^{20}$ - have followed the general framework laid down by the SDA 1975, defining discrimination (and victimisation and, latterly, harassment) and then rendering it unlawful with regard to particular activities (depending on the scope of the Act or Regulations). ${ }^{21}$ Thus section 1(1) of the SDA 1975 defined discrimination as either less favourable treatment on grounds of the complainant's sex (direct discrimination), or whereby the defendant applied something to both sexes but it adversely effected people of one sex and the defendant failed to establish that that adverse effect could be objectively justified (indirect

\footnotetext{
${ }^{17}$ Marriage (latterly joined by Civil Partnership) was protected under the seminal Sex Discrimination Act 1975 but it can hardly be considered to be a major protected characteristic given its rare use (see, eg J Hand, 'The curious case of marriage/civil partnership discrimination in Britain' (2012) IJDL 12(3) 166).

${ }^{18}$ The nine pieces being the Sex Discrimination Act 1975 (SDA 1975), Equal Pay Act 1970, Race Relations Act 1976 (RRA 1976), Disability Discrimination Act 1995 (DDA 1995), Employment Equality (Religion or Belief) Regulations 2003 (RB Regs 2003), Employment Equality (Sexual Orientation) Regulations 2003 (SO Regs 2003), Equality Act 2006, Employment Equality (Age) Regulations 2006 (Age Regs 2006) and Equality Act (Sexual Orientation) Regulations 2007 (SO Regs 2007).

${ }^{19}$ Such as the Race Relations Act 1976 and the Employment Equality (Age) Regulations 2006.

${ }^{20}$ Such as the Equality Act 2006 extending the protection from religion or belief discrimination to the provision of goods and services.

${ }^{21}$ The Disability Discrimination Act 1995 adopted a different template (and had different aims) but nonetheless still defined discrimination and then outlawed certain activities.
} 
discrimination). Subsequent sections rendered it unlawful to discriminate in, for example, offering employment (s.6(1)), dismissing someone (s.6(2)), providing education (s.22), providing goods and services (s.29), and so forth. While the framework was general there were a number of differences in definitions and scope, due in no small part to the effect of European Law (see below). These differences included, for example, the definition of direct discrimination for sex and age adopting a claimant-specific formulation (e.g. on grounds of her sex) whereas for race, religion or belief and sexual orientation the less favourable treatment did not have to be because of the claimant's own characteristic (and thus allowed claims by association or due to perception). There were also myriad precise definitions of indirect discrimination (but to the broad effect given above) and, in the case of religion or belief and sexual orientation, protection was spread over two pieces of legislation each (drafted using different indirect discrimination terminology). The Equality Act 2010 has brought a welcome rationalisation of definitions while retaining the general framework with the definitions of prohibited conduct followed by the prohibitions in the areas of goods, facilities, services and public functions (Part 3), premises (Part 4), work (Part 5), education (Part 6) and associations (Part 7). ${ }^{22}$

The province of tort over the Equality Act 2010, and the predecessor legislation, is clear. The various pieces of legislation explicitly made clear that in the non-employment cases, a claim 'may be made the subject of civil proceedings in like manner as any other claim in tort or (in Scotland) in reparation for breach of statutory duty'. ${ }^{23}$ While it is true that employment related claims - which are by far the most litigated - are reserved to the Employment Tribunal rather than a typical tortious

\footnotetext{
${ }^{22}$ While Pt 3 is titled 'Services and Public Functions', s 31(2) makes clear that this includes goods and facilities.

${ }^{23}$ Sex Discrimination Act 1975, s 66; claims were, and are, restricted to the County (or Sheriffs') courts but with all remedies as would be available in the High Court or the Court of Session (s 66(2)).
} 
jurisdiction, ${ }^{24}$ the provisions regulating compensation for wrongs in employment explicitly refer to the non-employment provision (such as that quoted above) and it is 'well established' that for the purposes of compensation they should be treated as a claim in tort. ${ }^{25}$ The Equality Act 2010, for the most part, consolidates the previous law and continues to define compensation for non-employment and employment-related discrimination in this way, although it now says that the county court has power to grant any remedy which could be granted in the High Court in proceedings in tort rather than, as formerly, referring to 'any other claim in tort' ${ }^{26}$

One area where the Equality Act 2010 initially developed the law is with regard to liability for harassment. Harassment may constitute a crime or a tort (and, indeed, the Protection from Harassment Act 1997 (PHA 1997) created both a criminal offence and a civil action) but it could also lead to an action for discrimination. A statutory definition and action of harassment within the anti-discrimination legislation was introduced in $2003^{27}$ but prior to this actions were brought under direct discrimination. In either case, the harassment or less favourable treatment had to be on grounds of the protected characteristic (be it 'her sex', 'religion or belief', 'racial grounds', etc.), but could afford greater protection than the PHA 1997 as there was no

\footnotetext{
${ }^{24}$ Eg Sex Discrimination Act 1975, s 63(1).

${ }^{25}$ See eg Alexander v Home Office [1988] 1 WLR 968, 975; Essa v Laing [2004] ICR 746 [36]-[39], [62], [117]; Abbey National Plc v Chagger [2009] ICR 624, [87]-[88], EAT. In Chagger v Abbey National Plc [2010] ICR 397, CA, Elias LJ referred to the claim being 'akin to a tort' at [11] despite the wording and precedence but to no effect. This can be contrasted with unfair dismissal: 'By contrast, the right not to be unfairly dismissed, with which Polkey was concerned, is a sui generis statutory right, the breach of which is not classifiable as a tort' (Abbey National Plc v Chagger [2009] ICR 624 at [87][88]).

${ }^{26}$ Ss 119 and 124(6) Equality Act 2010.

${ }^{27}$ With s 3A inserted into the Race Relations Act 1976 by reg 5 of the Race Relations Act 1976 (Amendment) Regulations 2003/1626; this was followed by the coming into force of the Employment Equality (Religion or Belief) Regulations 2003, the Employment Equality (Sexual Orientation) Regulations 2003. Section 3B of the Disability Discrimination Act 1995 was introduced in 2004 by reg 4(2) of the Disability Discrimination Act 1995 (Amendment) Regulations 2003/1673with s 4A Sex Discrimination Act 1975 being inserted a year later by reg 5 of the Employment Equality (Sex Discrimination) Regulations 2005/2467.
} 
requirement for a course of conduct. ${ }^{28}$ There will be further discussion of the definition below, under the EC/EU Law heading, as it was subject to judicial review, but of a particular note here is the liability of employers. In the late 1990s, the Court of Appeal held the liability of employers under the discrimination legislation was different from that under the common law or by extension the PHA 1997 (which uses common law vicarious liability). ${ }^{29}$ The discrimination legislation's use of the words 'whether or not it was done with the employer's knowledge or approval', within the provision conferring liability on the employer, placed a higher level of responsibility than at common law, as did the presence of the 'reasonable steps defence' in such provisions (otherwise the defence would mean that there was less protection in the discrimination statutes). There was also the concern that the common law test would mean that the more abhorant the act, the less likely the employer would be liable and thus the more likely the complainant would be unable to seek recompense. The subsequent change to the common law wrought by Lister $v$ Hesley Hall ${ }^{30}$ brought the two closer together but the two were set to diverge again when the Equality Act 2010, building on an amendment to the Sex Discrimination Act 1975, sought to make employers liable for the acts of third parties across the protected characteristics (but only where the employee had suffered such harassment at least twice before and the employer had failed to take reasonable steps). ${ }^{31}$ The Coalition Government, however, have now repealed this provision. ${ }^{32}$

\footnotetext{
${ }^{28}$ See eg Bracebridge Engineering v Darby [1990] IRLR 3, Insitu Cleaning Company Ltd v Heads [1995] IRLR 4.

${ }^{29}$ Jones $v$ Tower Boot [1997] 2 All ER 40. For the PHA see Majrowski v Guy's \& St. Thomas's NHS Trust [2005] EWCA Civ 251; B Barrett, 'The Protection from Harassment Act enters the workplace' (2005) 34 ILJ 261.

${ }^{30}$ [2002] 1 AC 215.

${ }^{31}$ Equality Act 2010, s 40(2)-(4).

${ }^{32}$ Enterprise and Regulatory Reform Act 2013, s 65.
} 
Alongside the prohibitory, retrospective approach in outlawing discrimination and harassment, three of the prior pieces of legislation latterly imposed positive duties on public authorities. ${ }^{33}$ These provisions laid out a general positive duty on public authorities to have due regard, when exercising their functions, to the need to eliminate unlawful discrimination and promote equality of opportunity with regard to Race, Disability and Sex. They also provided for specific duties designed to help the authorities meet their general duty. While the provisions were similar in concept there were various differences in structure and substance, with the racial duty taking a more prescriptive approach and imposing a wider duty encompassing the fostering of good relations alongside the promotion of equality of opportunity. The Equality Act 2010 has extended the duty across all the protected characteristics, ${ }^{34}$ adopting the broader scope of the RRA 1976 but with an even lighter touch than that required formerly by the SDA, omitting 'many of the detailed publication requirements' and rendering the duties 'significantly less bureaucratic'. ${ }^{35}$ Since its inception, only the Equality and Human Rights Commission has had the power to bring proceedings to enforce the specific duties, ${ }^{36}$ but the Equality Act 2010 has brought welcome clarification regarding the general duty. There was previously the untested possibility that the Race and Disability duties might give rise to a tortious action for breach of statutory duty

\footnotetext{
${ }^{33}$ Race Relations Act 1976, s 71 (inserted in 2000), Disability Discrimination Act 1995, s 49A (inserted in 2006), Sex Discrimination Ac 1975, s 76A (inserted in 2007).

${ }^{34}$ With the partial exception of Marriage/Civil Partnership which is excepted from the duty regarding advancing equality and fostering good relations ('relevant protected characteristics' for s 149(1)(b) \& (c) omitting that characteristic (by virtue of s 149(7)).

${ }^{35}$ Explanatory Memorandum to The Equality Act 2010 (Specific Duties) Regulations 2011 (para 7.3). The new specific duties can be summarized as requiring public authorities to 'prepare and publish [one or more] objectives, setting out what they intend to achieve in order to further the aims of the duty, and to publish information demonstrating their compliance with the duty.' (para 2.3 of the Explanatory Memorandum) . The Race Relations Act 1976's detailed data collection and the Disability Discrimination Act 1995's requirement to involve disabled people in the creation of the equality scheme have been removed and the express requirement to publish details of engagement with interested parties dropped following consultation.

${ }^{36}$ Equality Act 2006, s 32(11) (as amended 5 April 2011).
} 
but the 2010 Act follows the SDA in explicitly stating that the duties do not confer a cause of action at private law. ${ }^{37}$

The Equality Act 2010 and Property Law

Property Law is most closely engaged with the Equality Act 2010 through Part 4 of the Act 'Premises', one of the five parts outlawing discrimination by rendering it a tort. Under the old law, the Sex Discrimination Act 1975 and the Race Relations Act 1976 contained premises-related provisions within the broader Goods, Services, Facilities heading. Now, a distinct six section part prohibits discrimination in the disposal and management of premises and requires disability-related reasonable adjustments to be made. ${ }^{38}$ However, there also other areas which may have an impact on those dealing with property.

Indeed, the most high profile area currently where equality issues are associated with premises does not fall under Part 4 but what is now Part 3, the provision of services. Formerly, section 29 of the SDA, for example, provided examples of facilities and services and specifically included 'accommodation in a hotel, boarding house or other similar establishment'. ${ }^{39}$ While the corresponding provision in the Equality Act 2010 (also s.29) does not provide any such examples, section 32(3) holds that 'Part [4] does not apply to the provision of accommodation if the provision - (a) is generally for the purpose of short stays by individuals who live elsewhere'. Thus bed and breakfast accommodation and the controversy over homosexual couples being prohibited, by devoutly religious owners, from having a

\footnotetext{
${ }^{37}$ Equality Act 2010, s 156; Mark Bell provides a detailed account of enforceability of the positive duties in 'Judicial enforcement of the duties on public authorities to promote equality' [2010] Public Law 67.

${ }^{38}$ Equality Act 2010, ss 32-38; with specific exceptions in schs 4 and 5.

${ }^{39}$ Sex Discrimination Act 1975, s 29(2)(b).
} 
double bed is unlawfully discriminatory under Part $3 .{ }^{40}$ There has been some attempt to deny that bed and breakfasts amount to a boarding house or similar establishment as the number of meals provided in the former is less but this has been given short shrift by the courts. ${ }^{41}$ However, there is a peculiarity in that the Premises provisions include a small premises exception whereby if the premises are sufficiently small ${ }^{42}$ then some prohibitions regarding premises, such as offering a right to occupy, do not apply (unless the characteristic is race). ${ }^{43}$ Accordingly, where accommodation is provided to those who do not 'live elsewhere' the exception could be relied on whereas letting out rooms in the same size of property to those who are on holiday does not fall within this limited exception. ${ }^{44}$ This seems to give greater protection to holidaymakers than those in need of accommodation.

One area within Part 4 where the Equality Act 2010 has seen new law being introduced, but no yet brought into force, concerns the duty to make reasonable adjustments for disabled people. The requirement under the old Disability Discrimination Act 1995 has been extended to cover common parts of leasehold premises ${ }^{45}$ and Schedule 4, para 7(4) holds that if an agreement regarding such adjustments is made 'A's obligations under the agreement become part of A's interest in the common parts and pass on subsequent disposals accordingly.'

The Act is silent on how the agreement will bind the land and afford effective protection. The Landlord and Tenant (Covenants) Act 1995 makes clear that collateral

\footnotetext{
${ }^{40}$ Bull v Hall [2013] UKSC 73, [2013] 1 WLR; Black and Morgan v Wilkinson [2013] EWCA Civ 820, [2013] 1 WLR 2490.

${ }^{41}$ Black and Morgan $v$ Wilkinson [2013] EWCA Civ 820, [2013] 1 WLR 2490 at [9] - [13].

${ }^{42}$ Where the D and his/her household reside in one part and the other part is not sufficient to provide accommodation to more than 6 other people comprising no more than two other households (sch 5, para 3).

${ }^{43}$ Equality Act 2010, ss 33(1) and 35(1) prohibiting discrimination in the disposal of and management of premises, s 38(4) defining disposal and sch 5, para 3(2) excluding race.

${ }^{44}$ The Chymorvah private hotel in Bull v Hall would fall outside the exception as it has seven guest rooms ([2013] 1 WLR, [59]) whereas the Swiss Bed \& Breakfast in Black and Morgan has only 3 guest rooms ([2013] 1 WLR 2490, [1]).

${ }^{45}$ Equality Act 2010, s 36(1)(d).
} 
agreements, whether they are made before or after the creation of the lease, are to be treated like any other covenant and this may be the mechanism. ${ }^{46}$

Alternatively, it might be simply that the agreements will bind because paragraph 7(4) of Schedule 4 says they will. There is a lack of clarity here which may be among the reasons, along with practical difficulties, why the provision is among the few that have yet to be brought into force. Likewise, in order for the agreement to be noted on the land register, it would need to be established that the agreements in respect of common areas are 'interests' for the purposes of s.32 of Land Registration Act 2002 and that the exclusion of restrictive covenants should be read as allowing positive covenants to be protected. It may well be that there will be other changes introduced (perhaps to the Land Registration Rules 2003) which will clarify the situation rather than having clarified the situation at source.

A further provision, this time abolishing a legal principle but again not yet in force, is section 199 - the abolition of the presumption of advancement. The nature and scope of the presumption is not without ambiguity, but the explanatory notes state that the presumption is 'a presumption that a man who transfers property to his wife, child or fiancée is making the recipient a gift of that property, unless there was evidence to the contrary', ${ }^{47}$ whereas there is no such presumption when the transferor is a woman. The presumption has been criticized as belonging to a different era ${ }^{48}$ and it is clearly sex discriminatory but there were alternatives to abolition. As Lord Walker and Baroness Hale put it in Kernot $v$ Jones, that 'that problem might have

\footnotetext{
${ }^{46}$ s 28. The same approach will be taken with pre-1995 Act leases (see System Floors Limited $v$ Ruralpride Limited [1995] 1 EGLR 48 CA).

${ }^{47}$ The Explanatory Notes to The Equality Act 2010, 624.

${ }^{48}$ See, most famously, Lord Diplock in Petitt $v$ Pettitt [1970] AC 777, 824c who considered it to be 'an abuse of the legal technique for ascertaining or imputing intention to apply to transactions between the post-war generation of married couples "presumptions" which are based upon inferences of fact which an earlier generation of judges drew as to the most likely intentions of earlier generations of spouses belonging to the propertied classes of a different social era'.
} 
been solved had equity been able to extend the presumption of advancement to unmarried couples and remove the sex discrimination [but] the tool which equity has chosen to develop law is the "common intention" constructive trust'. ${ }^{49}$ In other jurisdictions, the presumption has been taken to include mothers as well as fathers, ${ }^{50}$ although it has been removed between spouses. ${ }^{51}$ A non-discriminatory amendment could have been passed in place of abolition, as happened with regard to the Married Women's Property Act 1964 (section 200 of the Equality Act 2010 if brought into force will see it transform into the Matrimonial Property Act 1964 wherein money and property derived from housekeeping money is shared equally whether the money came from husband to wife or wife to husband or indeed between civil partners). However, as Brightwell notes, "the change was made with no parliamentary debate, following the introduction of an amendment during the passage of the Act in the House of Lords'.52 The undue haste with which this amendment was made has to some extent, albeit less satisfactorily, been mitigated by the pronounced delay in deciding whether to bring it into force.

The Equality Act 2010 and Equity

The common law freedom to discriminate in disposition by gift or trust has, as Gardiner notes, generally been left untouched by the anti-discrimination legislation. ${ }^{53}$ Lord Wilberforce's dicta from 1975 that:

\footnotetext{
${ }^{49}$ [2011] UKSC 53, [24].

${ }^{50}$ See eg strong obiter in Pecore v Pecore, 2007 SCC 17 (CanLII), [2007] 1 SCR 795, [31] - [41] regarding infant children, Antoni v Antoni [2007] UKPC 10, [20] (parent and child), Anderson v McPherson [No 2] [2012] WASC 19, [140]-[141] citing Nelson v Nelson (1994) 33 NSWLR 740.

${ }^{51}$ Property (Relationships) Act 1976 (NZ), s 4(3)(a).

52 James Brightwell 'Good riddance to the presumption of advancement?' (2010) 16 Trusts \& Trustees 627,627 . The amendment was moved on the $6^{\text {th }}$ committee day HL Deb 9 February 2010 vol 717, col 711.

${ }^{53} \mathrm{~S}$ Gardiner, An Introduction to the Law of Trusts $2^{\text {nd }}$ ed. (Clarendon Law Series, OUP 2011), 65.
} 
Discrimination is not the same thing as choice: it operates over a larger and less personal area, and neither by express provision nor by implication has private selection yet become a matter of public policy, ${ }^{54}$

remains unchallenged in case law and by statute, it being applied well into the antidiscrimination law era, ${ }^{55}$. While Harding maintains that the common law could, in fact, eliminate such discriminatory trusts - either where a non-discrimination norm operates at a constitutional level or through application of Razian autonomy and the collective good $^{56}$ - Parliament has not opted not to do so through statute law.

Nevertheless, the Equality Act 2010 engages with the law of equity and trusts in a number of, albeit relatively minor, ways. Alongside the Act's late-inserted and illscrutinized abolition of the presumption of advancement (discussed above), the Act also harmonizes the limited incursion into the private sphere, regarding private associations, and amends the previous provisions regarding charities.

Previously, private associations were prohibited from discriminating against members only with regard to race, disability and sexual orientation. The general prohibition against discriminating in the provision of goods and services, such as that in section 29 of the Sex Discrimination Act 1975, did not apply to private associations as the section was limited to provision 'to the public or a section of the public' and only the Race Relations Act 1976, the Disability Discrimination Act 1995 and the Equality Act (Sexual Orientation) Regulations 2007 contained separate provision governing private associations (but only those whose membership was 25 or more and whose rules regulated admission to membership and involved a process of

\footnotetext{
${ }^{54}$ Blathwayt v Baron Cawley [1976] AC 397, 426; see also Lord Simon of Glaisdale at 427 ('it would appear that the policy of English law is to allow a testator considerable freedom in the way in which he disposes of his estate').

${ }^{55}$ Eg Nathan v Leonard [2003] 1 WLR 827, Ch. [11] ('the disposition of a deceased's estate is essentially a matter of private property; but in any event it is the policy of the law to uphold testamentary freedom).

${ }^{56}$ M Harding, 'Some arguments against discriminatory gifts and trusts' (2011) 31 OJLS 303.
} 
selection). ${ }^{57}$ The Equality Act 2010 extends this protection to the other protected characteristics (with the usual exception of marriage and civil partnership) and extends the protection for guests, previously only available with regard to disability, across the same characteristics. ${ }^{58}$ Thus a private members club who has members from both sexes must treat them equally but, under schedule 16, they may restrict membership to persons who share a protected characteristic.

The previous provisions allowing charities a partial exemption have been clarified, harmonized and extended beyond sex, race, sexual orientation and religion or belief to also cover disability and age (and, although the explanatory notes omit reference to them, it would appear also to gender reassignment and pregnancy and maternity). Thus charities may restrict the provision of benefits to persons who share a protected characteristic as long as they act in pursuance of a charitable instrument, and the provision of the benefits is either for the purpose of preventing or compensating for a disadvantage linked to the protected characteristic or is otherwise a proportionate means of achieving a legitimate aim. ${ }^{59}$ The Charity Commission consider this explicit requirement on charities to justify restrictions to be the key difference under the new Act (previously only the SDA explicitly contained such a requirement following an amendment in 2008$)^{60}$ but there are a couple of other new subsections worthy of note. Firstly, under section 193(5), charities may require members to make a statement which asserts or implies membership or acceptance of a religion or belief (but only if the charity imposed such a requirement before 18 May

\footnotetext{
${ }^{57}$ Race Relations Act 1976 ss 25-26, Equality Act (Sexual Orientation) Regulations 2007, reg 16.

${ }^{58}$ Equality Act 2010, ss 101 and 102; the limit to associations with 25+ members appears in s 107(2).

${ }^{59}$ Equality Act 2010, s 193(1),(2). The racial sub-characteristic of colour remains excluded from the exemption (Equality Act 2010, s 194(2); Race Relations Act 1976, s 34(3)).

${ }^{60} \mathrm{~S}$ 43(2A) Sex Discrimination Act 1975 inserted by The Sex Discrimination (Amendment of Legislation) Regulations 2008 (SI 2008/963), reg 2(1), Sch 1 para. 11. It has held to be implicitly required in the other legislation so as to comply with the European Convention on Human Rights 1950 (ECHR) (Catholic Care (Diocese of Leeds) v Charity Commission for England and Wales \& Anor [2010] EWHC 520 (Ch), [96].
} 
2005). ${ }^{61}$ This may allow some protection for religious charities but it is clearly, and peculiarly, limited. ${ }^{62}$ Secondly, section $193(7)$ makes clear that, for example, allwoman fundraising events (such as the Race for Life used to support Cancer Research UK) do not contravene section 29. This only applies to sex, however, and so, while all-homosexual groups or French groups are permitted under Schedule 16, a fundraising event limited to the wider all-homosexual or, for example, French community is not.

The Equality Act 2010 and Public Law

Public Law can be an amorphous concept. As Lord Diplock noted in $O^{\prime}$ Reilly $v$ Mackman 'the appreciation of the distinction in substantive law between what is private law and what is public law has itself been a latecomer to the English legal system. ${ }^{63}$ It can relate to all law that deals with the relationships between the individual and the State (and thus embrace criminal law) or more narrowly be shorthand for constitutional and administrative law or even solely administrative law, which is the sense in which Lord Diplock used it. ${ }^{64}$ The declaration of the seven foundations of legal knowledge includes criminal law as one of the seven and

\footnotetext{
${ }^{61}$ Equality Act 2010, s 193(6)(a).

${ }^{62}$ it would appear unlikely on the facts to avail any help to the Catholic adoption agency in Catholic Care (Diocese of Leeds) v Charity Commission for England and Wales \& Anor [2010] EWHC 520, [2010] 4 All ER 1041 who sought to rely on the exemption in the SO Regs 2007 by seeking to amend their instrument of government.

${ }^{63}$ [1983] 2 AC 237, 277.

${ }^{64}$ For a further example see JWF Allison in A Continental Distinction in the Common Law: A Historical and Comparative Perspective on English Public Law (OUP 2000) where he focused on 'public law in the sense of administrative law - the law relating to administrative authorities, powers, or functions' and excluded 'discussion of constitutional law as such and its relationship with private law' (p 3).
} 
adumbrates public law as including 'Constitutional Law, Administrative Law and Human Rights ${ }^{65}$ and it is in that context in which it is used here.

The Equality Act 2010 falls within the embrace of Public Law in a number of ways. Not only does it refine a core concept underpinning the law, both public and private, but discrimination within the provision of public services is among the specified areas where discrimination is prohibited as a statutory tort (unless subject to exceptions). ${ }^{66}$ In this respect it has harmonized the pre-existing provisions and extended the scope so that discrimination in the exercise of public functions because of pregnancy and maternity, because of a person's gender reassignment and, two years after the Act's initial commencement, because of a person's age are all now covered. The Act has also, as noted in the section on Tort above, expanded and harmonized the positive duties on public authorities across the protected characteristics and introduced the further, currently unimplemented, duty to take account of socio-economic inequalities. ${ }^{67}$ Furthermore, the Equality Act 2010 falls within the primarily administrative remedy of judicial review not only with regard to the enforcement of these duties but also, as discussed in the section on EU law, where the law fails to adequately implement EU directives.

It also occupies some of the same ground as the European Convention for the Protection of Human Rights and Fundamental Freedoms 1950 (ECHR). There are, however, clear distinctions between the two. For example, the ECHR discrimination

\footnotetext{
${ }^{65}$ Joint Academic Stage Board (JASB) (2012) Joint Academic Stage Board Handbook, Appendix B, 5 (Schedule 2, a. i.).

${ }^{66}$ The prohibition is in Equality Act 2010, s 29 and is subject to exceptions in schedule 3.

${ }^{67}$ Despite the prominent placing of the provisions right at the start of the Act, coverage of socioeconomic inequality was intended to be weaker than other matters. It did not fall within the protected characteristics and the duty was intended to be a lesser duty than that imposed by the other public duties, on a potentially different grouping of public authorities, simply requiring socio-economic inequalities to be considered when making strategic decisions. The Coalition Government declined to implement it on the basis that it was unnecessary and potentially damaging 'red tape' (Theresa May, Equality Strategy Speech (17 November 2010) <www.gov.uk/government/speeches/theresa-maysequality-strategy-speech> accessed 20 November 2010.
} 
provisions do not include the direct and indirect dichotomy that is a hallmark of the British and EU approach ${ }^{68}$ and the ECHR uses an open list approach to protected characteristics as opposed to the exhaustive list set forth in section 4 of the Equality Act $2010 .{ }^{69}$ Furthermore, as far as the UK is concerned, it has a much narrower scope as the prohibition against discrimination only relates to discrimination in the enjoyment of other convention rights rather than being a freestanding right in itself. ${ }^{70}$ Nonetheless, the Equality Act 2010, like its predecessor legislation, operate in overlapping spheres with the ECHR and British law has, for example, borrowed from the jurisprudence of the European Court of Human Rights when it comes to the definition of religion and belief, the drafters of the Equality Act 2010 and the earlier legislation having declined to define it. ${ }^{71}$

The Act also has some significance to constitutional law, not simply because it is an Act of Parliament but because of the circumstances of its passage into law.

Despite the novelty of interleaving the explanatory notes with the Bill so as to aid user

\footnotetext{
${ }^{68}$ E.g. Gill and Monaghan described the 'clear distinction' as '[o]ne of the strengths of UK discrimination law' (T Gill and K Monaghan, 'Justification in Direct Sex Discrimination Law: Taboo Upheld' (2003) 32 ILJ 115. The ECtHR does, however, recognize indirect discrimination as falling within the general concept expressed in the ECHR (see, e.g., DHv Czech Republic 31 EHRR 4) in the same way that disparate impact first emerged in the US initially through case law (Griggs v Duke Power 401 US 424 (1971); statutory wording was introduced some twenty years later (Civil Rights Act of 1991, 105 Stat 1071).

${ }^{69}$ The prohibition in Article 14 ECHR lists a number of grounds, such as sex, race, colour, political or other opinion, property and birth but finishes with the potential catch-all 'or other status'. This allows sexual orientation to be included while not expressly listed (Karner v Austria (2003) 38 EHRR 24). The approach in the Equality Act is to list the nine protected characteristics, providing a degree of legislative certainty, rather than follow the open list of the ECHR and others.

${ }^{70}$ Protocol 12 to the ECHR provides a general right not to be discriminated against in the enjoyment of any legal right (as opposed to convention rights as with Article 14) but the UK is one of 30 out of 47 signatories to the Convention not to have ratified that protocol (and one of ten not to have signed it) as of $10 / 02 / 2010$, see http://conventions.coe.int/Treaty/Commun/ChercheSig.asp?NT=177\&CM=1\&DF=10/02/2010\&CL=E NG (accessed 28 March 2014).

${ }^{71}$ During third reading of the Equality Bill in the House of Lords, Baroness Thornton stated 'European directives that relate to matters of religion or belief do not attempt to define specifically what the terms "religion" or "belief" mean; nor does Article 9 of the European Convention on Human Rights.

However, case law has identified the relevant factors that need to be taken into consideration...' (HL Deb 23 March 2010, vol 718, col 857). Such case law was case law of the ECtHR such as Campbell and Cosans v United Kingdom [1982] 4 EHRR 293. See also Grainger v Nicholson [2010] ICR 360 and Ewieda v British Airways plc [2009] ICR 303, [26]-[27].
} 
engagement, and it being a still rare example of a Bill introduced into one session of Parliament and then carried over into the following one, the scrutiny the Bill received was somewhat wanting. While Hepple asserts that the Act 'was the product of intense and detailed scrutiny in Parliament over a period of nearly a year', with the House of Commons Public Bill committee taking 38 hours and the Commons Report stage a further $5 \frac{1}{2}$ hours, ${ }^{72}$ parliamentarians in both chambers lamented the lack of time available for proper scrutiny with one noting that 'the Leader of the House will go down in history as having organized things in such a way that more amendments and new clauses than ever before have fallen without scrutiny in this place. ${ }^{, 73}$ This lack of scrutiny is evident in subsequent amendments, not just regarding the change from EC to EU law mentioned above ${ }^{74}$ but also to do such things as 'correct inadvertent omissions to ensure that... provisions of the 2010 Act work effectively in Scotland as well as England and Wales', ${ }^{75}$ remove an ambiguity concerning the duty to make reasonable adjustments for disabled persons where relationships have come to an end $^{76}$ and ensure that complainants' solicitors may continue to advise as to compromise agreements (following considerable clamour as the original wording unintentionally risked making such agreements unreliable). ${ }^{77}$ It can furthermore be

\footnotetext{
${ }^{72}$ B Hepple, Equality - the New Legal Framework (Hart 2011) 5.

${ }^{73}$ HC Deb 2 December 2009, vol 501, col 1193 (Dr Evan Harris); see also col 1183 (Mr Harper), cols 1225 - 1230 and HL Deb December 15, 2009, vol 715 col 1415 (Lord Lester).

${ }^{74}$ Articles 8 and 11 of the Equality Act 2010 (Consequential Amendments, Saving and Supplementary Provisions) Order 2010.

75 The Explanatory Notes to The Equality Act 2010 (Consequential Amendments, Saving and Supplementary Provisions) Order 20102010 No 2279. The provisions are ss 87, 132, 134 and 136 of the Act.

${ }^{76}$ The Explanatory Notes to the Act give an example whereby an employee's benefits include life-time use of the in-house gym facilities. The law as enacted suggested that the duty to make reasonable adjustments to enable a disabled ex-employee's use applied only where the complainant was disabled during his/her time as an employee. Article 5 of the Equality Act 2010 (Consequential Amendments, Saving and Supplementary Provisions) Order 20102010 No 2279 makes it clear that it applies to exemployees who subsequently become disabled.

77 The Equality Act 2010 (Amendment) Order 20122012 No 334; The Law Society led a campaign which saw 16,000 solicitors call for a change (see J Rayner 'Society wins clarity on independent advice' LSG (10 April 2012) and C Baksi 'Drafting error fears over Equality Act ' LSG (4 November 2010).
} 
seen in such legislative peculiarities as the status of pregnancy/maternity

discrimination. While that protected characteristic has its own dedicated provisions in sections 17 and 18 and it is the one characteristic explicitly excluded from the indirect discrimination provision, there is no such exclusion from the definition of direct discrimination within section 13 . However, section 25 sets out in one place what is meant by references to particular strands of discrimination and while it refers to sections 13 and 19 for all the other grounds it mentions only sections 17 and 18 for pregnancy/maternity. Thus if section 25 is taken to be authoritative, the Act on the face of the section explicitly limits one crucial concept (that of indirect discrimination) from applying to pregnancy discrimination but implicitly limits it from applying to another (direct discrimination). As other sections - such as those defining and prohibiting harassment - explicitly delimit their application such omission from section 13 would be highly curious, at least. If section 25 is mere guidance, then such ambiguous guidance is of little worth. Either way, here as with other areas, further legislative scrutiny could have clarified the drafting and intention. $^{78}$

The Equality Act 2010 and EC/EU law

British discrimination law has both national and European origins. British discrimination law has developed endogenously - covering areas which EU law was

\footnotetext{
${ }^{78}$ It could of note that of the nine protected characteristics, all bar pregnancy/maternity have defining sections immediately following the section 4 list. However, any suggestion that pregnancy/maternity should not be in the section 4 list is rebutted by its sole exclusion in the list of 'relevant' protected characteristics in section 19(3). A further example of a lack of scrutiny can be seen in the dual discrimination provision; introduced late in the day during the $\mathrm{HC}$ committee stage, there was very little consideration of it (" $\mathrm{t}]$ here was no debate on the point in the Commons during the report stage or at Third Reading and only brief mentions during Second Reading in the House of Lords' (J Hand, 'Combined Discrimination - section 14 of the Equality Act 2010: a partial and redundant provision?' [2011] Public Law 482-490, 486) leading to inconsistent argument being unchallenged and unnecessary complexities retained.
} 
slower to embrace such as the grounds of race and disability and the provision of goods and services - as well as being subject to European Law, which gave rise both to the introduction of new provisions (such as the grounds of sexual orientation and religion or belief and the introduction of distinct harassment provisions) and the frequent amendment of existing ones. This disparate development caused there to be no fewer than three definitions of indirect discrimination in force in British law for a time, with the Sex Discrimination Act 1975 and Race Relations Act 1976 both containing two active definitions. This was due to the operation of section 2(2) of the European Communities Act 1972, the mechanism by which the EC Directives were transposed into national law. It left the original definitions of discrimination to apply to areas outside EC law but given the different trajectories of the two overlapping jurisdictions the definitions applied to different matters within the two Acts. Accordingly, the EU definition applied solely to the field of employment within the SDA (until it was extended to goods and services in 2008) ${ }^{79}$ but applied across the fields in the RRA 1976 but only with regard to the sub-grounds of race, national and ethnic origin with the original national definition remaining for colour and nationality. Furthermore, following the EC broadening the scope of its anti-discrimination legislation the Disability Discrimination Act 1995 was subject to radical amendment rendering it an extreme alphabet-soup of inserted sections (with sections $3-7$ (excluding section 5 which was repealed in 2004), 14, 16-18, 21, 22, 24, 28, 31, etc. all having lettered sections inserted after them including section 28UA-UC inserted after section 28U and even sections 31ADA and 31ADB). The Equality Act 2010 has certainly rationalized the legislation in these respects.

\footnotetext{
${ }^{79}$ By Schedule 1 para 1of the Sex Discrimination (Amendment of Legislation) Regulations 2008/963.
} 
The doctrine of indirect effect, requiring domestic law to be interpreted so far as possible in such a way that it complies with relevant Directives, ${ }^{80}$ and to challenge by judicial review if it does not adequately reflect European law, can also be seen in the jurisprudence surrounding equality law (both forming the background for, and already playing a part in jurisprudence on, the Equality Act 2010). An extreme example of such judicial interpretation can be seen in EBR Attridge Law LLP \& Anor $v$ Coleman ${ }^{81}$ where entire subsections were implied into the Disability Discrimination Act 1995 so as to bring it into compliance with EU law regarding the protection of carers. ${ }^{82}$ The Equality Act 2010 no longer requires such considerable indirect 'reading in' as the unified direct discrimination definition allows such associative claims. With regard to judicial review, one such review, concerning the definition of harassment within the Sex Discrimination Act 1975, led to one of the few novel and controversial provisions in the Equality Act 2010. In Equal Opportunities Commission v Secretary of State for Trade and Industry, ${ }^{83}$ the EOC sought, among other things, to show that the Sex Discrimination Act's use of 'on the grounds of her sex' did not adequately transpose the directive which refers to 'conduct related to the sex of a person' and that the legislation failed to implement the Directive in not introducing or enabling employers' liability for the acts of third parties. While Burton J agreed that the definition section needed to be recast to remove both the causation, or as he put it the 'ratiocination', element and the limitation to the complainant's own sex, he considered that the introduction of liability arising from the acts of third parties would be a consequence of such a change rather than something explicitly or implicitly

\footnotetext{
${ }^{80}$ Marleasing SA v Comercial Internacional de Alimentacion SA C-106/89 [1991] I-ECR 4135

${ }^{81}$ [2010] ICR 242.

${ }^{82}$ Such interpretation does have limits as noted in Dunn $v$ The Institute of Cemetery and Crematorium Management [2012] ICR 941, [45]-[48]. The case also considered whether the duty of purposive interpretation required it to add words from a repealed Directive so as to give rights for acts committed before its repeal [51].

${ }^{83}$ [2007] EWHC 483, [2007] ICR 1234.
} 
mandated by the directive. ${ }^{84}$ However, when the government amended the SDA 1975 they not only changed the wording of the definition but also introduced a separate provision making employers liable where they had failed to take reasonable steps and were aware that an employer had been harassed on more than two occasions by a third party. This provision was expanded across the seven relevant protected characteristics for harassment in the Equality Act 2010 but the coalition government considered the provision to be unworkable and an unnecessary burden on business and repealed it in 2013.85

A concept of European law is arguably directly responsible for a further peculiarity of harassment within the Equality Act 2010. While there are nine protected characteristics detailed in section 4 , and seven relevant protected characteristics for harassment, ${ }^{86}$ when it comes to the prohibition of harassment in such areas as the provision of goods and services the number falls to five. ${ }^{87}$ The protected characteristics of pregnancy/maternity and marriage/civil partnership are excluded from the definition of harassment, the government being of the view that any pregnancy or maternity harassment would be 'related to her sex' in any case and that there was little or no evidence to justify the inclusion of harassment related to marriage or civil partnership. ${ }^{88}$ The further exclusion of religion or belief and sexual orientation from the list of relevant protected characteristics for harassment in the provision of good and services (and in such areas as housing, education and public services) is, however, due to concerns of incompatibility with freedom of expression

\footnotetext{
${ }^{84}$ [2007] EWHC 483, [2007] ICR 1234, [40] ('there is nothing explicit, or even arguably implicit, in any of the Articles requiring a Member State to impose vicarious liability on an employer, or indeed liability for negligent failure to take steps').

${ }^{85}$ It was estimated that the provision cost business $£ 0.3 \mathrm{~m}$ a year (HM Treasury, The Plan for Growth (2011), 53. S 40(2)-(4) were repealed by Enterprise and Regulatory Reform Act 2013, s 65 with effect from 1 October 2013.

${ }^{86}$ Equality Act 2010, s 26(5).

${ }^{87}$ Equality Act 2010, s 29(8) (originally only four as age was delayed until the provision was brought into force for age by the Equality Act 2010 (Commencement No. 9) Order 2012/1569).

${ }^{88}$ Equality Bill Deb 18 June 2009, col 318 (Vera Baird).
} 
and manifesting religious belief due to specific ground and area concerns (with examples including booksellers censoring books, restraining proselytizing landlords and impeding the explanation of sincerely held beliefs for fear of merely creating an offensive environment). ${ }^{89}$ This fear of incompatibility is in turn due to the British government, when implementing the Race Directive, adopting a disjunctive approach, rather than the directive's conjunctive approach, in the definition of harassment because of previous British case law and the European concept of non-regression. Many pieces of European legislation covering employment rights contain a 'nonregression' clause preventing member states from 'leveling-down' or using the implementation of European law as an excuse to reduce the protection they previously offered. ${ }^{90}$ The government, when consulting on the implementation of the Race and Equality Directives back in 2001, noted that 'Employment Tribunals normally define harassment [within direct discrimination] as unwanted conduct of a racial or sexual nature or other conduct based on race or sex affecting the dignity of men and women at work' ${ }^{91}$ They thus considered that the statutory definition of harassment, with regard to Race and Sex, must include the disjunctive 'or' rather than the directives' 'and' when defining harassment (the chosen formulation being unwanted conduct with the purpose or effect of a) violating a person's dignity or b) creating an

\footnotetext{
${ }^{89}$ Department for Communities and Local Government, Discrimination Law Review - A Framework for Fairness: Proposals for a Single Equality Bill for Great Britain (2007), para 14.17; HL Deb 9 November 2005, vol 675, cols 648 - 653 (Lord Lester); Joint Committee on Human Rights, Legislative Scrutiny: Equality Bill (Twenty-Sixth Report of 2008/2009) para 112; Joint Committee on Human Rights, Legislative Scrutiny: Sexual Orientation Regulations (Sixth Report of Session 2006-07), paras 56-58.

${ }^{90}$ Eg Article 6(2) of Council Directive 2000/43/EC (the Race Directive) holding that 'The implementation of this Directive shall under no circumstances constitute grounds for a reduction in the level of protection against discrimination already afforded by Member States in the fields covered by this Directive'. See also Article 8(2) of Council Directive 2000/78 (the Framework Equality Directive); Clause 8(3) of the Annex to Council Directive 1999/70/EC (the Fixed-Term Workers Directive); Clause 6(2) of the Annex to Council Directive 97/81/EC (the Part-Time Workers Directive). ${ }^{91}$ Cabinet Office, DTI, Home Office and DWP, Towards Equality and Diversity: Implementing the Employment and Race Directives (December 2001) para 6.3; such wording being based on the EC Recommendation and Code of Practice on measures to combat sexual harassment at work (91/131/EEC) (adopted in GB by Reed \& anor $v$ Stedman [1999] IRLR 299, EAT).
} 
intimidating, hostile, degrading, humiliating or offensive environment). This

argument carried through to the Equality Act with the Solicitor General saying in committee that

To use the conjunctive approach — the European approach, which is perhaps slightly narrower-would be regression. We would be going back from what we have already done and we are not allowed to do that under the principle of non-regression. ${ }^{92}$

There is, however, some argument against this proposition. Firstly, when implementing the Framework Employment Equality Directive, as Barmes notes '[t]here was, quite simply, no pre-existing UK law on age, religion and belief or sexual orientation [with] which to compare the Employment Directive' and thus no danger of regression. ${ }^{93}$ The choice was open to adopt differences in definition to reflect the differences in characteristic or activity (for example, deleting some of the lesser adjectives regarding the atmosphere whilst retaining protection from the more serious ones $)^{94}$ but it was decided to opt for a binary consistency or nothing. ${ }^{95}$ Furthermore, the non-regression clause holds that implementation of the directive shall not constitute grounds for a reduction in the level of protection but does not necessarily act as a standstill (which would prevent the reduction of standards absolutely). ${ }^{96}$ Whilst it is clear that implementation may take place on more than one

\footnotetext{
${ }^{92}$ Equality Bill Deb 18 June 2009, col 318 (Vera Baird).

${ }^{93}$ L Barmes, 'Constitutional and Conceptual Complexities in UK Implementation of the EU Harassment Provisions' (2007) 36 ILJ 446, 451.

${ }^{94}$ Joint Committee on Human Rights, Legislative Scrutiny: Sexual Orientation Regulations (Sixth Report of Session 2006-07), paras 56-58.

${ }^{95}$ Which in turn led to the curiosity of s 212(5) which allows harassment to be construed as a detriment in circumstances where a provision has disapplied the prohibition on harassment in relation to a specified protected characteristic (s 212(1) holding that generally detriment does not include conducy which amounts to harassment) so that the old direct discrimination claim for harassment can for that characteristic be made.

${ }^{96}$ S Peers, 'Non-regression Clauses: The Fig Leaf Has Fallen' (2010) 39 ILJ 436, 442; Soysal v Germany (C-228/06) [2009] ECR I-1031.
} 
occasion, ${ }^{97}$ there may be room to argue that a change in definition seeks to better observe ECHR provisions rather than implement the directive. ${ }^{98}$ Barmes maintains that the original decision to adopt the disjunctive approach was flawed as the preexisting national law, as clarified by Pearce v Governing Body of Mayfield School ${ }^{99}$, did not require it ${ }^{100}$ but, notwithstanding the earlier position, having now legislated it is apparent that the extant provisions are subject to the prohibition of regression with regard to implementation. ${ }^{101}$ Barmes also raised the intriguing prospect of the harassment provisions being ultra vires as they were transposed into national law through secondary legislation under section 2(2) of the European Communities Act 1972 which may not allow for a more generous definition than required under EU law. ${ }^{102}$ This is at least something that the Equality Act 2010, being primary legislation, has resolved.

The principle laid down in Van-Gend en $\operatorname{Loos}^{103}$ that EU law is supreme (within its seemingly ever-increasing cognisance) has meant that the Act of 2010 has already been seen to need amendment. Some amendments are of little consequence, such as replacing references to 'Community law' with 'EU law' belatedly recognising the coming into force of the Treaty of Lisbon amending the Treaty on European

\footnotetext{
${ }^{97}$ Mangold v Helm (C-144/04) [2006] All ER (EC) 383, [51].

${ }^{98}$ For a full discussion of the value of non-regression clauses, see S Peers, 'Non-regression Clauses: The Fig Leaf Has Fallen' (2010) 39 ILJ 436 (where he holds that 'It is now clear from the case law that the non-regression clauses in EU social legislation are entirely, or very nearly entirely, ineffective' (at 439)).

${ }^{99}$ [2003] UKHL 34, [2003] ICR 937.

${ }^{100} \mathrm{~L}$ Barmes, 'Constitutional and Conceptual Complexities in UK Implementation of the EU Harassment Provisions' (2007) 36 ILJ 446, 450.

${ }^{101}$ This would not prevent a separate definition being used for the areas currently outside European law and while a draft directive is on the horizon it is likely that the concept of harassment will be defined in accordance with national law and the practices of Member States.

(European Parliament Press Release, 'European Parliament backs new anti-discrimination directive' <www.europarl.europa.eu/sides/getDoc.do?pubRef=-//EP//TEXT+IMPRESS+20090401IPR53200+0+DOC+XML+V0//EN> accessed 24 January 2014).

${ }^{102}$ L Barmes, 'Constitutional and Conceptual Complexities in UK Implementation of the EU Harassment Provisions' (2007) 36 ILJ 446, 450-452.

${ }^{103}$ (C26/62) [1963] ECR 1; R v Secretary of State for Transport Ex p Factortame Ltd (C221/89) [1992] QB 680 .
} 
Union and the Treaty establishing the European Community, ${ }^{104}$ while others are of greater significance. The striking down by the ECJ of Article 5(2) of the Gender Directive (2004/113/EC), which allowed member states, if supported by genuine statistical data, to derogate from the principle that insurers should not use gender as a risk factor, in Test-Achats ${ }^{105}$ has caused the government to reluctantly consult on deleting paragraph 22 of Schedule 3 to the Act which implemented Article 5(2) into national law despite the judgment going 'against the grain of the common sense approach to equality which the UK Government want to see'. ${ }^{106}$ The House of Commons European Scrutiny Committee noted that 'there is no scope for the Government to challenge the ECJ judgement' and recognized that 'it is not compatible with the UK's attachment to the rule of law to ignore the judgement'. ${ }^{107}$ Potential future challenges could arise regarding the 'occupational requirement' provisions. Schedule 9 provides for occasions when the prohibition on discrimination in employment is disapplied where there is a justifiable occupational requirement for somebody to have - or not have - a particular protected characteristic. The second paragraph concerns employment for the purposes of an organized religion whereby an employer may require a person to be of a particular sex, sexual orientation or marital state if such a requirement is so as to comply with the doctrines of that religion or so as to avoid conflicting with the strongly held religious convictions of a significant number of the religion's followers. As Pitt notes this may be subject to challenge as a 'reasoned opinion from the European Commission in 2009 suggested that this exemption is too broad to be compatible with the Framework Directive' and yet

\footnotetext{
${ }^{104}$ OJ C 306 Volume 50 (17 December 2007) in force from 1 December 2009; for the belated recognition see The Explanatory Notes to The Equality Act 2010 (Consequential Amendments, Saving and Supplementary Provisions) Order, SI 2010/2279.

${ }^{105}$ C-236/09 Association Belge des Consommateurs Test-Achats ASBL and Others $v$ Conseil des ministres [2011] 2 CMLR 38.

${ }^{106}$ HC Deb 30 June 2011, vol 530, col 53WS (Harper).

${ }^{107}$ European Scrutiny Committee, 'Fifty-Fifth Report' HC (2010-2012) 428-I [4.9].
} 
changes to the definition were voted down in the House of Lords. ${ }^{108}$ The third paragraph specifically covers employers with an ethos based on religion or belief and provides that they may apply 'in relation to work a requirement to be of a particular religion or belief' if they can show that, 'having regard to that ethos and to the nature or context of the work' it is an occupational requirement, its application constitutes a proportionate means of achieving a legitimate aim and that the person subject to the requirement either does not meet it or the employer has reasonable grounds for not being satisfied that the person meets it. Hepple contends that 'this does not accurately reflect the directive' which requires more than 'having regard' to the nature or context of the work. ${ }^{109}$ A further opportunity missed in the Equality Act 2010 was continuing to exempt Sections 58-60 of the School Standards and Framework Act 1998 from the prohibition on discrimination (this appears in Schedule 22(4) rather than Schedule 9 but has similar effect with regard to restricting certain employees to a particular religion). The Joint Committee on Human Rights considered there were 'substantial grounds' for doubting whether those sections 'as currently framed are compatible with the requirements of Article 4(2) of the Framework Equality Directive 2000/78/EC'. ${ }^{110}$ Doubts which, as McColgan puts it, 'appear to have fallen on deaf ears'. ${ }^{111}$

The Equality Act 2010 and criminal law

\footnotetext{
${ }^{108}$ G Pitt, 'Keeping the Faith: Trends and Tensions in Religion or Belief Discrimination' (2011) 40 ILJ 384,402 . Hepple considers that the defeat in the Lords does not alter the reading in of a proportionality test as mandated by the doctrine of indirect effect and applied by the High Court in the predecessor legislation in $R$ (Amicus) \& Others $v$ The Secretary of State for Trade and Industry [2004] EWHC 860 (Admin) but it should be noted that reasoned opinion (Infringement No 2006/2450) post-dated that case and applies to more than the proportionality point (ie the negativing of protected characteristics).

${ }^{109}$ B Hepple, Equality - the New Legal Framework (Hart 2011); the reference to the directive is to 2000/78/EC, Art 4(2).

${ }^{110}$ Joint Committee on Human Rights, Legislative Scrutiny: Equality Bill (Twenty-Sixth Report of 2008/2009) para 306.

${ }^{111}$ Aileen McColgan, 'Equality Act 2010', Institute of Employment Rights 2010 (Dec 2010), para 23.
} 
While the Equality Act's enforcement mechanism is predominantly tortious in nature, and criminal law primarily combats discriminatory behaviour through public order and disorder legislation, ${ }^{112}$ the Equality Act not only replicates some, albeit limited, criminal offences from the predecessor legislation but has highlighted their presence and sought to add them along with having a general regulatory effect on the criminal litigation process.

The limited criminal sanction in the Equality Act follows practice established in the early days of anti- discrimination in the 1960s, even before the seminal model was established, where criminal sanctions were almost completely excluded from the Race Relations Acts 1965 and 1968. ${ }^{113}$ The arguments advanced in Cabinet discussions were that the primary means of eliminating discrimination should be a conciliation mechanism (or in some fields non-statutory consultation). It was feared that the prospect of criminal proceedings might exacerbate local tensions and prejudice conciliation, with the public/private divide being noted in the minutes: [t]he Bill already provided heavy criminal sanctions against incitement to racial hatred; but this was an offence against public order and must be differentiated from an infringement of personal rights of a kind which constituted a primarily civil complaint. ${ }^{114}$

Nevertheless, there was still a view that the Government's attitude should be that discriminatory conduct was so repugnant that it was right to regard it as a criminal

\footnotetext{
${ }^{112}$ eg Various 'hate crimes' under the Crime and Disorder Act 1998 and the Public Order Act 1986 effectively criminalize some forms of extreme discriminatory behaviour (such as those in Public Order Act 1986, Pt 3 and Pt 3A concerning racial hatred and hatred on grounds of religion or sexual orientation) and the Protection from Harassment Act 1997 complements the statutory tort of harassment in Equality Act 2010, s26 with a criminal offence in s 2 (as well as other offences in ss 2A (stalking) and 4 (fear of violence)).

${ }^{113}$ For more on the background to the 1965 Act see eg Philip N. Sooben, 'The Origins of the Race Relations Act'(1990)Warwick Research Paper in Ethnic Relations No.12< http://web.warwick.ac.uk/fac/soc/CRER_RC/publications/pdfs/Research\%20Papers\%20in\%20Ethnic\% 20Relations/RP\%20No.12.pdf > accessed 24 February 2004.

${ }^{114}$ CONCLUSIONS of a Meeting of the Cabinet held at 10 Downing Street, SW1, on Thursday, 20th May, 1965 National Archives Ref: CAB/128/39.
} 
offence and this has carried over into limited offences. Clearly the criminal law was ultimately, and is, not seen as a significant tool in achieving the anti discrimination purpose of the general anti-discrimination legislation - or the promotion of equality. Nonetheless, like its predecessors the Equality Act does create specific criminal offences. These occur principally in Part 8 - titled Prohibited Conduct: Ancillary and Part 12 - Disabled Persons: Transport. Part 12 concerns taxi accessibility for wheelchair users, duties of taxi drivers carrying passengers in wheelchairs, carrying assistance dogs for blind people etc. It also gives the Secretary of State power to make regulations concerning the accessibility of Public Service Vehicles for disabled people. Failure to comply with regulations is punishable summarily by a fine usually at levels 3 or 4 on the standard scale.

The ancillary prohibited conduct in Part 8 is very specifically targeted. Section 110 imposes criminal liability on an employer or principal who knowingly or recklessly makes a false or misleading statement to an employee or agent to the effect that doing 'something' is not a contravention of the act. If the employee or agent then reasonably relies on that statement to do the 'something' then the employer or agent who made the statement commits a criminal offence punishable summarily by a fine not exceeding level 5 on the standard scale. Section 110 is complemented by section 112. Under this section, if a person knowingly helps another to contravene various parts of the Act, and the help was rendered in reasonable reliance on a statement that what was done would not contravene the Act, but the statement was false or misleading, and the maker knew or was reckless that the statement was false or misleading, then the maker of the statement would again commit an offence punishable summarily by a fine not exceeding level 5 on the standard scale. The effect of Part 8 is therefore to impose criminal liability on those in positions of power, 
authority or influence, who give incorrect assurances that people will not contravene the Act. Although the offences are summary, and the maximum punishment is a fine, the prospect of criminal conviction ought to operate personally upon those able to influence the behaviour of others. Nonetheless, and perhaps counter intuitively, according to Bindman, the imposition of wider criminal sanctions in the US to deter discriminatory behaviour was unsuccessful, leading to primarily administrative means in the US and Britain. ${ }^{115}$

Finally, section 78 allows regulations to be made with require employers to publish gender pay gap information. Following the usual form of such provisions, section 78(5) provides that the regulations may also make failure to publish an offence punishable summarily by a fine not exceeding level 5 on the standard scale. This section, and the prospect of criminal sanction in the event of a breach, should, if it were to have been brought into force, force employers to recognize where gender pay gaps exist. Identification of the problem should be the first step towards its elimination but currently, in an echo of the 1960s, the government are seeking to achieve equality here through non-statutory means. ${ }^{116}$

Apart from the specific offences created by the Act, the tenor of enforcement follows the pattern set in the 1960s and seems to lie in the civil sphere with actions primarily being brought by individuals and others in the County Courts or the Employment Tribunal, although proceedings for judicial review, and those relating to immigration and education be brought in appropriate fora (see Part 9 - Enforcement). There is no mention of any criminal court. Indeed the Equality Act seems to draw a careful line between itself and criminal proceedings. Section 113(7) specifically excludes the application of Part 9 - Enforcement - to proceedings for an 'offence'

\footnotetext{
${ }^{115}$ G Bindman, 'The Law and Racial Discrimination: Third Thoughts' (1976) 3 British Journal of Law and Society 110, 110-111.

${ }^{116}$ Government Equalities Office, ‘The Equality Strategy - Building a Fairer Britain’ (2010), 14.
} 
under the Act. Section 136, governing the burden of proof, specifically declares it does not apply to criminal proceedings brought under the Act (s136(5)) (in distinction to the predecessor sections), ${ }^{117}$ while section $119(7)$ prevents a county court from granting a remedy other than the award of damages or a declaration unless satisfied that no criminal matter would be prejudiced by doing so. Section 138 is an interesting provision which appears to be heavily influenced by the criminal law's insistence on the privilege against self-incrimination. Effectively, the section requires a respondent to give information in answer to a question from a claimant. Failure to provide such information within 8 weeks of the question being asked allows the court or tribunal to draw an adverse inference by virtue of section 138(4). However, such an inference cannot be drawn if the failure to respond might have prejudiced a criminal matter or would have revealed the reason for not commencing or not continuing criminal proceedings (s138(5). Again, it seems as if the Act acknowledges criminal law principles but wishes to be insulated from them.

The Equality Act 2010 and the Law of Contract

British anti-discrimination law is primarily tortious but there are areas where contracts are either affected or utilized. Indeed, Part 10 of the Equality Act 2010 is titled 'Contracts, etc.' and contains sections which render discriminatory terms unenforceable, but only so far as they have discriminatory effect, ${ }^{118}$ and which allow for such terms to be removed or modified. ${ }^{119}$ Furthermore, the torts themselves can be seen, on the surface, to infringe freedom of contract - depriving people of their ability, for example, to choose freely whom to employ or supply services to -

\footnotetext{
${ }^{117}$ see eg SDA 1975, s 63A.

${ }^{118}$ Equality Act 2010, s 142(1).

${ }^{119}$ Equality Act 2010, s 143(1).
} 
although there is a contrary body of thought that such prohibitions could in fact support freedom of contract, ${ }^{120}$ which, indeed, is 'premised on the notion of equal parties'. ${ }^{121}$ While British anti-discrimination law does not use contract as tool to the same extent as in, for example, the European Draft Common Frame of Reference, ${ }^{122}$ contract does feature notably in the areas of equal pay and the public sector duty.

Under the previous legislation, the matters of equal pay (and other contractual terms) between the sexes, on the one hand, and of tortious discrimination, on the other, were dealt with by separate Acts. The Equal Pay Act 1970 and the Sex Discrimination Act 1975 were intended to form a harmonious code but used different mechanisms, whereas all the subsequent protected characteristics included pay and terms within the tortious prohibition of discrimination in employment. The Equal Pay Act 1970 sought to prevent disparate pay based on sex through implying, if not expressly included, an 'equality clause' into contracts of employment. This clause operated to modify any less favourable term in a woman's contract (compared to a man's and vice versa), and to include in the contract any beneficial term which appeared in the comparator's contract but not hers, where the woman was employed on 'like work', 'work rated as equivalent' or 'work of equal value' with a man in the same employment.

\footnotetext{
${ }^{120}$ by, for instance, allowing people to contract who would otherwise be arbitrarily excluded; A Rafi, 'Gleichheit durch Kontrahierungszwang', (2005) 41 Recht und Politik 218 cited in F C Ebert \& T Pinkel, 'Restricting Freedom of Contract through Non-Discrimination Provisions?' (2009) 10 German Law Journal 1417, 1425; G Demeyere, 'Discrimination, Freedom, and the Limits of Contract' (2009) 10 International Journal of Discrimination and the Law (4) 219; D Kimel, 'Neutrality, Autonomy, and Freedom of Contract' (2001) 21 OJLS 473.

${ }^{121}$ S Fredman, Discrimination Law $2^{\text {nd }}$ ed (OUP 2011) 5 (although it should be noted that that is 'an abstract contractual equality which was oblivious to market reality').

${ }^{122}$ The Draft Common Frame of Reference (DCFR) is an attempt by groups of European lawyers to develop definitions, principles and rules of European Contract law and, more broadly, Private Law based on the law within member states. While the DCFR extends beyond contract, its nondiscrimination provisions may be enforced through contract: 'The DCFR does not contain a specific set of remedies for acts of discrimination. Art II - 2:104 of the DCFR provides that a victim of discrimination may be availed of 'the remedies for non-performance of an obligation under Book III, Chapter 3[ie the general remedies for breach of contract]' (F C Ebert \& T Pinkel, 'Restricting Freedom of Contract through Non-Discrimination Provisions?' (2009) 10 German Law Journal 1417, 1433).
} 
The Equality Act 2010, despite the aim to simplify and clarify the law, retains this distinction and largely replicates the previous law, with Hepple lamenting that 'the legislation remains unnecessarily complex and to some extent unintelligible'. ${ }^{123}$ The government decided to retain the distinction because, among other things, 'the implied contractual equality provision provides a valuable guarantee to women in the workforce of their right to be employed on the same terms as men'. ${ }^{124}$ There are clear disadvantages to treating sex differently from the other protected characteristics: such as the blurred line between contractual and non-contractual benefits risking claims becoming inadmissible if brought under the wrong heading (if not brought in the alternative) ${ }^{125}$ and sex having a harsher requirement regarding comparators (as the others can use hypothetical comparators). There are, however, some benefits to using contract and $70 \%$ of the respondents to the government consultation favoured retaining the distinction. The difference in the nature of the claims is reflected in the time limits and remedies. Whereas those claiming under the employment tort have three months to bring any claim, ${ }^{126}$ a claimant bringing a contractual claim generally has six months from the ending of employment to bring a claim to the employment tribunal $^{127}$ and if they are time-barred there then, unless the failure to bring the claim in the tribunal amounted to an abuse of process, they could issue a claim for breach of contract in the courts where the normal limitation period of six years applies. ${ }^{128} \mathrm{~A}$ corollary to this is that claims for equal pay being based in contract do not allow for

\footnotetext{
${ }^{123}$ B Hepple Equality - the New Legal Framework (Hart 2011) 98.

${ }^{124}$ Government Equalities Office, The Equality Bill - Government response to the Consultation $(\mathrm{Cm}$ 7454, 2008) para 7.58 .

${ }^{125}$ Hosso v European Credit Management Ltd [2012] ICR 547.

${ }^{126}$ Equality Act 2010, s 120(1); employment claims must be brought in the Employment Tribunal (the time limit for, eg, goods and services claims in the County Court is, by contrast, six months (s 118(1)).

${ }^{127}$ Equality Act 2010, s 129(1); different starting dates apply if the case concerns concealed facts, incapacity or stable work.

${ }^{128}$ Birmingham City Council v Abdulla and others [2011] EWCA Civ 141, [2012] 2 All ER 591; affirmed by Birmingham City Council v Abdulla and others [2012] UKSC 47, [2013] 1 All ER 649.
} 
damages for injury to feelings, which are routinely recoverable in the tort, or for aggravated or exemplary damages. ${ }^{129}$

In a step forward for transparency and aiding the fight for equality of pay, the Equality Act 2010 does contain a novel provision that limits the effect of pay 'gagging' clauses. Section 77 provides that terms that purport to prevent or restrict a person from disclosing information about his or her terms or seeking disclosure from colleagues about theirs are unenforceable but only where the disclosure is for the purposes of discovering whether there is a link between the pay for that particular work and a protected characteristic. This was preferred to making pay audits mandatory, with EEF (the manufacturers' organization) recording its members as being strongly against such audits considering them too expensive and burdensome and the government preferring to wait and see what impact voluntary audits have. ${ }^{130}$

Similar fears as to expense and burden led to the public sector duties being made less bureaucratic. As noted above, the Equality Act 2010 saw the general duty on public authorities to have regard to the need to eliminate unlawful discrimination, promote equality of opportunity and foster good relations, expanded to cover all the protected characteristics but the accompanying specific duties were simplified. ${ }^{131}$ Thus the government has not sought to use the power in section 155(2) that 'Regulations... may impose duties on a public authority that is a contracting authority within the meaning of the Public Sector Directive in connection with its public procurement functions'. However, the duty on public authorities can be carried

\footnotetext{
${ }^{129}$ Newcastle Upon Tyne v Allan \& Ors; Degnan v Redcar \& Cleveland BC [2005] ICR 1170; Watts v Morrow [1991] 1 WLR 1421 at 1445 F-G; Addis v Gramophone Co Ltd [1909] AC 488; Johnson v Unisys [2003] 1 AC 518.

${ }^{130}$ Government Equalities Office, The Equality Bill - Government response to the Consultation $(\mathrm{Cm}$ 7454, 2008) para 4.31-4.32.

${ }^{131} \mathrm{Eg}$ requirements to publish all details of engagement with interested parties when determining policies and equality objectives (as well as to publish the equality analysis undertaken and information used within that analysis), detailed data collection formerly required by the RRA 1976 and the obligation to involve disabled people in the creation of the disability equality scheme were all dropped in the simplification process.
} 
horizontally onto contracting businesses, where it is relevant and proportionate to do so, and as the public sector spends up to $£ 175$ billion $^{132}$ through contracts with the private sector that could amount to significant leverage. ${ }^{133}$ The Equality and Human Rights Commission Guidance suggests including two contract conditions prohibiting the contractor from unlawfully discriminating under the Equality Act 2010 and requiring them to take all reasonable steps to ensure that staff, suppliers and subcontractors meet their obligations under the Act - which do no more than require them to act lawfully, ${ }^{134}$ but there is scope to go further 'if the authority considers it necessary or expedient to do so to enable or facilitate compliance with a duty'. ${ }^{135}$

\section{Conclusion}

This article does not seek to suggest that equality law - however important and valuable a topic it might be - should become a foundation of legal knowledge in its own right in England and Wales (or elsewhere) but rather to show that the Equality Act 2010 and the jurisprudence around it are linked, to varying extents, to all the foundations. To this extent it suggests that the foundations, as currently understood, have some validity in educating practitioners and academic commentators in an area of law which has a high profile and a profound, often controversial effect on individuals and society. The exclusion of a subject from the list of foundations does

\footnotetext{
${ }^{132}$ Equality Bill Impact Assessment Version 4 (House of Lords Introduction) (HMSO, December 2009), 180.

${ }^{133}$ For a historic international review of such contract compliance through public procurement see, eg, C McCrudden, 'Using public procurement to achieve social outcomes' (2004) 28 Natural Resources Forum 257.

${ }^{134}$ Equality \& Human Rights Commission, 'The Essential Guide to the Public Sector Equality Duty England' (January 2012) 17.

${ }^{135}$ Local Government Act 1988, s 17(10) (as amended by Para 10 of Schedule 26 to the Equality Act 2010). A further example of contract compliance is facilitated by the Public Services (Social Value) Act 2012 with regard to the broader area of improving the economic, social and environmental wellbeing of the relevant area (which is to insert s17(11) into the Local Government Act 1988).
} 
not necessarily render the subject less important, as they build on the foundations laid by the others. Of course, legal knowledge extends well beyond the foundations and it is not a pre-requisite to have knowledge of all of them. To have some familiarity, however, allows a broader appreciation of the multitude of topics that flow from them, providing a useful foundation when looking to 'break into new areas' (in the words of the joint announcement by the England and Wales professional bodies) - and particularly helps to appreciate as broad a topic as equality law as embodied in the Equality Act 2010. 